\title{
EDUKASI PERAN REMAJA DALAM PENCEGAHAN COVID-19 PADA SISWA SMA/SMK DI MALANG
}

\author{
THE EDUCATION OF YOUTH ROLE IN PREVENTING COVID-19 AMONG HIGH SCHOOL \\ STUDENTS IN MALANG
}

\author{
Anggraini Dwi Kurnia ${ }^{1}$, Nur Melizza ${ }^{2 *}$, Nur Lailatul Masruroh ${ }^{3}$, Yoyok Bekti Prasetyo ${ }^{4}$ \\ ${ }_{1,2,3,4}$ Program Studi Ilmu Keperawatan Fakultas Ilmu Kesehatan UMM, Indonesia \\ Email: melizza@umm.ac.id
}

\begin{abstract}
ABSTRAK
COVID-19 merupakan penyakit yang bisa menyerang semua kalangan tak kecuali dengan remaja. Remaja yang terserang COVID-19, meniliki gejala ringan bahkan cenderung orang tanpa gejala. Sehingga sangat rentan untuk melakukan penyebaran COVID-19 jika tidak melakukan protocol kesehatan dengan baik dan benar Tujuan dari pengabdian adalah meningkatkan pengetahuan peran remaja dalam melakukan pencegahan COVID-19 pada siswa-siswi SMA/SMK se Malang Raya. Metode yang dilaksanakan yakni bekerja sama dengan prodi Keperawatan D3 Universitas Muhammadiyah Malang dengan melakukan zoominar dengan sasaran siswa SMK/SMA sejumlah 108 siswa. Evaluasi yang dilakukan dengan cara memberikan posttest setelah pemberian edukasi. Hasil yang didapatkan dengan cara memberikan posttest setelah pemberian edukasi, dengan hasil pengetahuan tentang peran remaja dalam melakukan pencegahan COVID-19 pada siswa-siswi SMA/SMK se Malang Raya meliputi: kurang (4\%), pengetahuan cukup (60\%), dan baik (36\%). Setelah dilakukan zoominar, pemahaman siswa dalam peran remaja dalam melakukan pencegahan COVID-19 mengalami peningkatan. Hal ini diperlukan mengingat remaja menjadi role model bagi temannya.
\end{abstract}

Kata kunci: Remaja, Covid-19, Pencegahan

\section{ABSTRACT}

COVID 19 is a disease that can affect all people, including teenagers. Adolescents who are infected with COVID 19, have mild symptoms and even tend to be asymptomatic. So, it is very vulnerable to spread COVID 19 if you do not carry out health protocols properly and correctly. The purpose of this service is to increase knowledge of the role of youth in preventing COVID 19 among high school/vocational high school students throughout Malang Raya. The method implemented is collaborating with the D3 Nursing study program at the University of Muhammadiyah Malang by conducting a zoominar targeting high school students. Evaluation is done by giving a posttest after giving education. The results obtained by giving a posttest after providing education, with the results of knowledge about the role of adolescents in preventing COVID 19 in high school / vocational students in Malang Raya include: less (4\%), sufficient knowledge (60\%), and good (36\%). After the zoominar, students' understanding of the role of youth in preventing COVID 19 has increased. This is necessary considering that teenagers are role models for their friends

Keywords: Teenagers, Covid-19, Prevention 


\section{PENDAHULUAN}

Pemerintah Republik Indonesia telah melaporkan 257.388 orang dengan COVID-19 yang dikonfirmasi sampai dengan 23 September 2020. Ada 9.977 kematian terkait COVID-19 yang dilaporkan dan 187.958 pasien telah pulih dari penyakit tersebut. WHO bekerja sama dengan Pemerintah Indonesia untuk memantau situasi dan mencegah penyebaran penyakit lebih

25 persen $\geq 70$ tahun: 5,85 persen Berdasarkan data tersebut, diketahui bahwa dari seluruh kasus yang dikonfirmasi positif Covid19 di Indonesia, pasien pada kelompok usia 1029 memiliki 17,69 persentase (Mukaromah, 2020).

Tidak hanya kelompok usia lanjut ataupun mereka yang memiliki penyakit penyerta saja yang berpotensi terjangkit COVID 19. Remaja dengan imunitas yang bagus juga rawan tertular virus COVID 19, walaupun dengan gejala yang sangat minimal. Pada kelompok usia muda atau remaja memiliki daya tahan tubuh yang lebih baik, namun harus diperhatikan bahwa bukan berarti kelompok remaja ini menjadi kebal dan mereka juga bisa terkena dan tanpa gejala. Orang yang tanpa gejala (silent carrier) yang menjadi salah satu faktor penyebaran virus corona semakin cepat. Hal ini dikarenakn yang bersangkutan tidak menyadari telah terjangkit COVID-19 dan tidak melakukan physical distancing (Makarim, 2020).

Solusi yang ditawarkan pada pengabdian ini yakni berupa sosialisasi dan memberikan edukasi pentingnya remaja mengetahui perannya dalam melakukan pencegahan COVID 19 seperti memakai masker dengan benar, Mencuci tangan secara rutin dan melakukan physical distancing.

\section{METODE}

Solusi permasalahn ini akan diselesaikan dengan melibatkan siswa SMA/SMK se Malang Raya sejumlah 108 siswa meliputi SMK Muhammadiyah 7 Gondang Legi, SMKN 2 Malang, SMA Widyagama Malang, SMK NU Sunan Ampel Poncokusumo, SMK Muhammadiyah 1 Kota Malang. Pengabdian masyarakt ini melalui platform zoominar dengan memaparkan materi tentang peran remaja dalam pecegahan COVID -19 dan diakhiri dengan kegiatan evaluasi berupa pemberian posttest. Sejumlah 20 soal terdapat dalam posttest dan berikan melalui slide power point. Solusi lanjut (WHO Indonesia, 2020). Di Kota Malang per tanggal 24 September 2020 jumlah penderita terkonfirmasi positif sejumlah 1756 orang (Pemerintah Kota Malang, 2020).

Seluruh pasien positif Covid-19 yang dikonfirmasi, berikut adalah rincian persentase kelompok usianya: 0-9 tahun: 1,53 persen 10-29 tahun: 17,69 persen $30-49$ tahun: 38,69 persen 50-69 tahun: 36, prioritas permasalahan mitra dilakukan secara riil adalah :

1. Pemberian edukasi tentang peran remaja dalam pencegahan COVID-19 dengan melibatkan prodi keperawatan D3 dalam melakukan zoominar dengan sasaran siswa SMA/SMK se Malang Raya untuk menurunkan masalah kurang pengetahuan tentang peran remaja dalam pencegahan COVID-19.

2. Mitra berpartisipasi dalam mengikuti kegiatan dengan platform zoominar

\section{HASIL DAN PEMBAHASAN}

Kegiatan pengabdian masyarakat dilaksanakan selama kurun waktu \pm 1 bulan mulai tahap persiapan sampai tahap evaluasi. Jadwal kegiatan yang direncanakan adalah pemberian penyuluhan tentang Covid-19 pada remaja dengan target sasaran siswa/siswi SMA dan SMK. Lebih detailnya, rincian kegiatan yang telah dilaksanakan sebagai berikut:

1. Tahap Persiapan

Koordinasi dengan mitra, persiapan flyer, persiapan promosi penyelenggaraan Zoominar yang dilaksanakan mulai bulan agustus 2020

2. Tahap Pelaksanaan

Penyuluhan tentang peran remaja dalam pencegahan COVID-19 pada tanggal 24 September 2020 meliputi:

a) Penyuluhan tentang peran remaja dalam pencegahan COVID-19

b) Diskusi tentang issue peran remaja dalam pencegahan COVID-19 yang bisa dilihat dari gambar 1 .

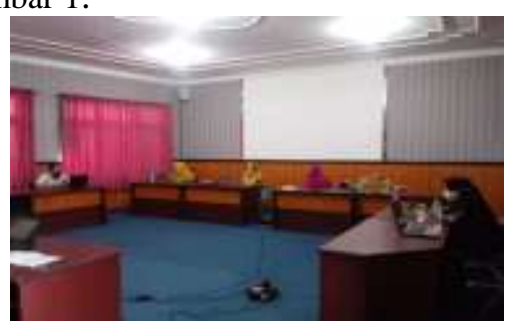


Gambar 1. Pelaksanaan Zoominar

\section{Tahap Evaluasi}

Pemberian post-test dilakukan setelah pelaksaan zoominar serta mengobservasi kehadiran dan keaktifan peserta zoominar.

Kegiatan pengabdian masyarakat ini membawa dampak positif dan menambah pengetahuan siswa/mitra. Mitra sangat antusias mengikuti kegiatan zoominar dan mereka mendapat ilmu baru. Adapun capaian hasil meliputi berikut ini:

1. Peserta zoominar mencapai 108 orang.

2. Pengetahuan peserta terkait peran remaja dalam pencegahan COVID-19 dengan presentase: Pengetahuan kurang (4\%), Pengetahuan Cukup (60\%), dan Baik $(36 \%)$.

3. Antusias peserta seminar sangat baik, dibuktikan dengan banyak pertanyaan yang masuk.

Dalam pelaksanaan kegiatan pengabdian ada beberapa kendala, kendala tersebut dapat diatasi oleh tim sehingga dapat diatasi. Kendala yang dihadapi adalah : 1) Keterbatasan waktu presentasi dan diskusi, karena dalam pelaksanaan zoominar diisi oleh lebih dari 2 pemateri solusinya : tim membatasi masingmasing pemateri dan penanya, pertanyaan yang belum terjawab dijawab melalui chat selama pemateri selanjutnya melakukan penyuluhan.

\section{KESIMPULAN}

Remaja sangat berperan dalam pencegahan COVID-19. Pengetahun siswa tentang perannya dalam mencegah COVID-19 sangat membantu dalam penyebaran COVID-19. Untuk itu pemahaman tenang peran remaja ini sangat membantu dalam implementasi remaja dalam mencegah COVID-19. Pengetahuan siswa/siswi/peserta setelah dilakukan kegiatan zoominar ini adalah pengetahuan kurang (4\%), pengetahuan cukup (60\%), dan baik (36\%).

\section{DAFTAR PUSTAKA}

Makarim, F. R. (2020). Tak Pandang Usia, Kaum Muda Juga Bisa Terinfeksi Virus Corona.

https://www.halodoc.com/artikel/kaummuda-juga-bisa-terinfeksi-virus-corona

Mukaromah, V. F. (2020). 9.511 Positif Virus Corona, Ini Rincian Usia Pasien Covid-19 di Indonesia. https://www.kompas.com/tren/read/2020/0 4/29/121700365/9.511-positif-viruscorona-ini-rincian-usia-pasien-covid-19-diindonesia-?page $=$ all

Pemerintah Kota Malang. (2020). Peta Persebaran Covid-19 di Kota Malang per $24 \quad$ September 2020. https://malangkota.go.id/2020/09/24/petapersebaran-covid-19-di-kota-malang-per24-september-2020/

WHO Indonesia. (2020). Update on coronavirus disease in Indonesia. https://www.who.int/indonesia/news/novelcoronavirus 